ISSN 0103-5150

Fisioter. Mov., Curitiba, v. 30, n. 2, p. 367-377, Apr./June 2017

Licenciado sob uma Licença Creative Commons

DOI: http://dx.doi.org/10.1590/1980-5918.030.002.A017

\title{
Prevalence and factors associated with low back pain in elderly registered in the Family Health Strategy
}

\author{
Prevalência e fatores associados à dor lombar em idosos \\ cadastrados na Estratégia de Saúde da Família
}

\author{
Natasha Mendonça Quintino ${ }^{[\mathrm{b}]}$, Marta Helena Souza De Conti ${ }^{[a]}$, Roger Palma ${ }^{[\mathrm{b}]}$, \\ Márcia Aparecida Nuevo Gatti ${ }^{[a]}$, Sandra Fiorelli Almeida Penteado Simeão ${ }^{[a]}$, Alberto De Vitta ${ }^{[a]^{*}}$
}

[a] Universidade do Sagrado Coração (USC), Bauru, São Paulo, Brazil

[b] Universidade Paulista (UNIP), Bauru, São Paulo, Brazil

\begin{abstract}
Introduction: Low back pain has varied etiology and complex discussed and can be triggered by various factors. Objective: Was to assess the prevalence of low back pain in individuals 60 years or more of the areas of the Family Health Strategy "Vila Sao Paulo" in the city of Bauru, São Paulo, and its association with demographic and socioeconomic variables, relating to work, lifestyle and morbidity. Methods: We conducted a cross-sectional study with 363 elderly sampled by the technique of two-stage cluster, which were interviewed at home using a multidimensional instrument (demographic, socio-economic, featuring work; lifestyle; morbidity) and the Nordic questionnaire. Conducted descriptive analysis, bivariate and Poisson regression. Results: It was noted more frequently in the elderly age group between 60 and 69 years old, married, with low education and income from two to five. The prevalence of low back pain was $55.8 \%$ of elderly patients studied, $52.2 \%$ in men and $47.8 \%$ women and, the variables load and carry weight $(p=0.001)$ and the number of diseases referred to $(p=0.04)$ showed association with the presence of low back pain.
\end{abstract}

\footnotetext{
NMQ: BS, e-mail: natashamq@hotmail.com MHSC: PhD, e-mail: madeconti@yahoo.com.br RP: MS, e-mail: rg_palma@yahoo.com.br MANG: PhD, e-mail: marciangatti@gmail.com SFAPS: PhD, e-mail: ssimeao@usc.br AV: PhD, e-mail: albvitta@gmail.com
} 
Conclusion: The elderly respondents show a high prevalence of low back pain associated with the loading and transport weight and the number of diseases referred.

Keywords: Low back pain. Epidemiology. Aging. Risk Factors.

\section{Resumo}

Introdução: A dor lombar tem etiologia variada e complexa podendo ser desencadeada por diversos fatores. objetivos: Verificar a prevalência de dor lombar em indivíduos de 60 anos ou mais das áreas de abrangência da Estratégia Saúde da Família "Vila São Paulo" na cidade de Bauru, São Paulo e, sua associação com as variáveis demográficas, socioeconômicas, relativas ao trabalho, estilo de vida e morbidade referida. Métodos: Realizou-se um estudo transversal com 363 idosos amostrados pela técnica de conglomerado em dois estágios, os quais foram entrevistados nos domicílios utilizando um instrumento multidimensional (aspectos demográficos; sócio-econômicos; caracterização do trabalho; estilo de vida; morbidade referida) e o questionário Nórdico. Realizaram-se análise descritiva, bivariada e regressão de Poisson. Resultados: Notou-se maior frequência de idosos na faixa etária entre 60 e 69 anos, casados, com baixa escolaridade e com renda de dois a cinco salários mínimos. A prevalência de dor lombar foi 55,8\% do total de idosos estudados, sendo 52,2\% nos homens e 47,8\% nas mulheres e, as variáveis carregar e transportar peso ( $p=0,001)$ e o número de doenças referidas $(p=0,04)$ mostraram associação com a presença de dor lombar. Conclusão: Os idosos entrevistados apresentam uma alta prevalência de dor lombar associada às atividades ocupacionais que exigem carregamento e transporte de peso e ao número de doenças referidas.

Palavras-chave: Dor lombar. Epidemiologia. Envelhecimento. Fatores de Risco.

\section{Introduction}

The Brazilian Institute of Geography and Statistics (IBGE) estimated that in 2002 elderly people corresponded to $9.3 \%$ of the Brazilian population, $10.5 \%$ in $2007,8.6 \%$ in 2009 , raising the possibility that, in 2020 , Brazil will have 25 million elderly people, in other words, $11.4 \%$ of the estimated population and thus making the ageing population phenomenon a reality (1).

However, data published by the Demographic Census in 2010 demonstrated that, in Brazil, the percentage of elderly people has reached $11.3 \%$ of the population and the city of Bauru, São Paulo, for the first time, presented a greater number of older people in relation to children under 5 years age, being the proportion 38.075 elderly people to 25.199 children (1).

The ageing population process brought the benefits of a longer life; however, in addition, it also brought a new profile of morbid-mortality, characterized by an increase (accumulation) in chronic degenerative diseases and their many complications such as osteoarthritis, osteoporosis, spinal pains among others (2).

Low back pain has become a serious public health problem, because, besides plaguing elderly people, it also has a high incidence in the economically active population, adolescents and children. "Low back pain is a condition which affects approximately $11.3 \%$ of the world population and, in Brazil, around 10 million people become incapacitated because of this morbidity and, at least $70 \%$ of the population will have an episode of this type of pain in life" (3).

Considering studies that point out reports of low back pain in elderly people, one notes the prevalence of such dysfunction in $21.6 \%$ of the elderly population in the USA (4), 61.8\% in Belo Horizonte (5), 47.7\% in in the southwest of Bahia (6), 29.5\% in Goiânia (7) and $25.4 \%$ in the city of São Paulo (8).

Low back pain may be associated with gender, education, the decrease in flexibility and mobility of the muscles, obesity, competitive sports, postural habits, ergonomic occupational and household factors, sedentary lifestyles (time in front of the TV and the computer), levels of physical activity, smoking and others $(3,9)$.

Some studies show that low back pain is associated with functional disability $(7,8)$, depression (4), the perception of poor health (7), low school levels $(3,10)$, age, gender, marital status, smoking habits 
and the occupational activities that require working in lying down position, repetitive motion routines and the load and transport of weight (3).

This set of factors can decrease the quality of life through unsuccessful treatments, it can cause a reduction in the functional performance and physical capacity of elderly people in carrying out daily, leisure or occupational activities, with their families or in society, it can trigger physical and psychological exhaustion in them and in their families/caregivers, it can cause dependence on medicinal drugs and difficulties at work. Moreover, it can lead to irritation, suppress the appetite and cause severe physiological, mental and social consequences $(11,12)$.

Another important point is that low back pain is a musculoskeletal disorder with a high prevalence and a high cost for the State, generating expenses with treatment and rehabilitation. Moreover, getting to know the sociodemographic and behavioral profiles, work habits and general health of this group of people and the factors associated with low back pain is essential for the development of public policies aimed at controlling this problem, based on preventive and/ or therapeutic interventions.

Taking into account the theoretical background, this study was developed with the objective of verifying the prevalence of low back pain in people 60 years old or over, from areas of influence covered by the Family Health Strategy (FHS) "Vila São Paulo" in the city of Bauru, São Paulo, Brazil and its association with the demographic, socioeconomic, work, lifestyle and referred morbidity variables.

\section{Methods}

Cross-sectional study of a population of individuals, 60 years old and over, in the areas covered by the Family Health Strategy "Vila São Paulo" in the city of Bauru, São Paulo, Brazil. The city of Bauru (SP) is located in the central western region of the state, with an estimated population of 366,992 inhabitants in 2015.

\section{Subjects}

The target public of this research was limited to elderly people that live in the Family Health Strategy confined areas, in the neighborhood of Vila São Paulo, northern region of Bauru, São Paulo. This area has two FHS teams with eight community workers. This region consists of four districts: Vila São Paulo, Jardim Ivone and Pousada da Esperança I and II, with an estimated population of approximately 12,600 residents.

To determine the sample size, a calculation formula for finite populations was applied. This calculation determined the sample to be 267 elderly people and it was based on an estimated prevalence of $50 \%$ (7). The reference population was based on 643 registered patient records. It was adopted a confidence level of $95 \%$, sampling error of $3 \%$ and design effect $=1.5$. The sample was expanded to 363 elderly people, considering a possible loss of $30 \%$ in participants, and mainly, because of the incorporation of various other objectives to the study, including among them an epidemiological investigation of hypertension and functional capacity.

For the sample selection, the community health workers provided lists of names (each name received a number) and addresses of all elderly people enrolled in the FHS of the neighborhood and, from that list, the study participants were chosen by drawing lots.

\section{Data Collection Procedure}

Data collection was performed from December 2011 to March 2012, by two students/researchers from the Physiotherapy Course of Universidade do Sagrado Coração (USC) in Bauru, both supervised by a postgraduate student of the Master's Degree Program in Dentistry, in the concentration area of Public Health. The research was approved by the Ethics Committee of the Universidade do Sagrado Coração (USC), process number 201/11.

The researchers visited the homes covered by the FHS program, accompanied by community workers of each sector, in order to collect the interviews with the elderly participants. People with disabilities, such as mentally disabled people and those who have had a stroke, were exempted from answering the questionnaire. In case no one could be found at home after three attempts, or if there was failure to respond to the questionnaire, another elderly participant was drawn from the list.

Data were collected through a pre-coded questionnaire, with closed questions, in which demographic (gender, age, marital status and skin color), socioeconomic (education and income), behavioral (physical activity level and smoking), ergonomic (work sitting, standing, squatting, lying, kneeling, vibration and/ or trepidation, weight lifting, repetitive motion) and 
morbidity variables were considered. All these variables were considered as independent from each other.

The level of physical activity among adults and elderly patients was assessed using the International Physical Activity Questionnaire - (IPAQ), short version, proposed by the World Health Organization (WHO) and by the Centers for Disease Control and Prevention CDC - (13).

Ergonomic variables were characterized by the respondent's perception after identifying, among four options (never, rarely, often, always), which one best characterized the frequency of exposure in relation to the activity the respondent performed when he/she was a worker or the one in which he/she still works at the time of the interview. Among the variables gauged we have physical exertion, vibration and repeatability, as well as a vicious position characterized by the frequency in which the respondent worked sitting, standing, squatting, lying down or kneeling. To define the association between low back pain and ergonomic variables, the frequencies obtained in the categories "never" and "rarely" were added and classified into a single group. The same was done in the categories "often" and "always" $(3,14)$.

The referred morbidity was collected through interviews in which the subject answered the question: "Among the alternatives below (heart disease, hypertension, cerebrovascular accident (CVA), diabetes mellitus, cancer, arthritis, respiratory disease, depression, osteoporosis and disease of the genital and urinary system), point one (or more) that corresponds to a diagnosis that you have received from a doctor in the last 12 months" (15).

The dependent variable - low back pain — was observed by means of the Nordic questionnaire, adapted to the Brazilian culture (16). Low back pain was defined as pain or discomfort in the last twelve months, not related to trauma or any other problem. At the moment of the interview, the following question was asked to the elderly participants: "Did you experience low back pain last year?". To show the specific location of the pain, in addition to the verbal interrogation, an image featuring the regions of the vertebral column in different colors was presented to the participants so that they could identify the lumbar region.

\section{Data Analysis Procedure}

The obtained data were inserted into a database and the analyses were stratified by gender using the
SPSS statistical program, version 10.0 (SPSS, Chicago, United States). Distributions of absolute and relative frequencies were performed for categorical variables and a bivariate analysis was performed through the Pearson's chi-square test. To analyze the variables associated to low back pain, Poisson regression was used. This technique is justified since the outcome of the study can present a high prevalence $(20 \%$ or more), which would result in an overestimation of the magnitude of the effect measure, or odds ratio (OR), obtained by using logistic regression analysis. The prevalence ratios (PR) were calculated, as well as their respective confidence intervals (CI) of 95\%.

\section{Results}

In the family health strategy were studied 363 elderly people, being already discounted the final percentage of $3.2 \%$ of refusal and $1.2 \%$ of exclusion. Table 1 shows the sociodemographic characteristics, related diseases and physical activity levels of the elderly participants.

Table 2 shows characteristics of ergonomic variables - movements performed at work - of the elderly participants.

The prevalence of low back pain in the analyzed elderly people was $55.8 \%$ in general, being $52.2 \%$ in men and $47.8 \%$ in women. It is observed, in Table 3 , the statistically meaningful associations between low back pain and the number of referred morbidities and physical activity level.

The bivariate analysis among ergonomic variables - movements performed at work - and low back pain can be seen in Table 4 .

The results from the Poisson's regression analysis can be seen in Table 5 .

\section{Discussion}

The sociodemographic characteristics of the studied population match with national researches $(5$, $15,16,17)$. In relation to work characteristics, the elderly people of this study performed, mainly, the transport and lifting of weight, both standing and standing and leaning the body. Silva, Fassa and Valle (3) note that the studied population was exposed to vibration and/or trepidation and activities involving the transport and lifting of weight. 
Table 1 - Distribution of absolute and relative frequencies of sociodemographic characteristics, referred morbidity and physical activity level of the elderly participants

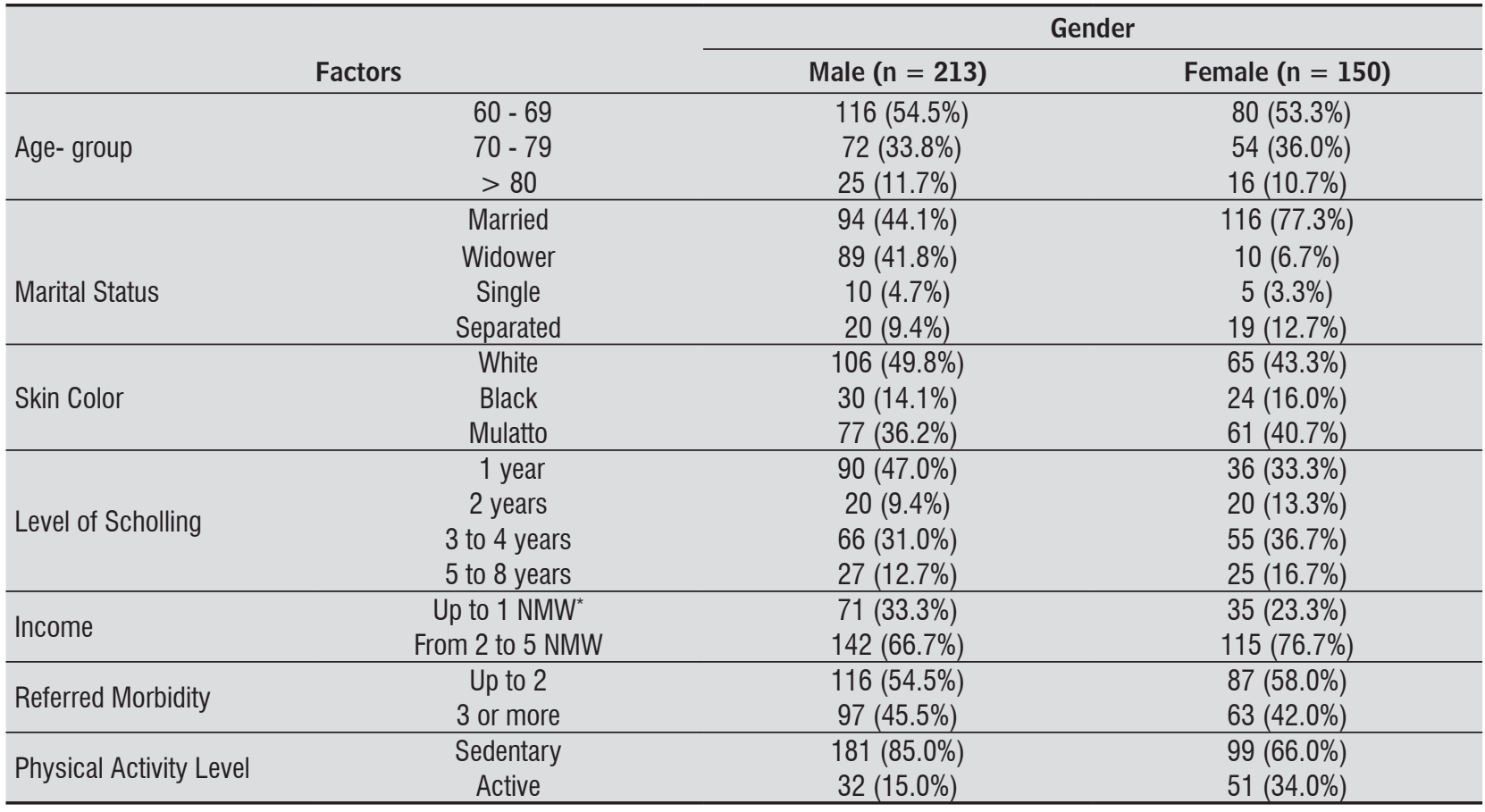

Note: * National Minimum Wage.

Table 2 - Distribution of absolute and relative frequencies of ergonomic characteristics of the elderly participants

\begin{tabular}{|c|c|c|c|}
\hline \multirow[b]{2}{*}{ Factors } & \multirow[b]{2}{*}{ Answer } & \multicolumn{2}{|c|}{ Gender } \\
\hline & & Male $(n=213)$ & Female $(n=150)$ \\
\hline \multirow{4}{*}{ Repetitive Movements } & Never & $17(8.0 \%)$ & $9(6.0 \%)$ \\
\hline & Rarely & 29 (13.6\%) & $9(6.0 \%)$ \\
\hline & Usually & $19(8.9 \%)$ & $25(16.7 \%)$ \\
\hline & Always & $148(69.5 \%)$ & $107(71.3 \%)$ \\
\hline \multirow{4}{*}{ Vibration and/or trepidation } & Never & $81(38.0 \%)$ & $27(18.0 \%)$ \\
\hline & Rarely & $67(31.5 \%)$ & 33 (22.0\%) \\
\hline & Usually & $57(26.8 \%)$ & $42(28.0 \%)$ \\
\hline & Always & $8(3.8 \%)$ & $48(32.0 \%)$ \\
\hline \multirow{4}{*}{$\begin{array}{l}\text { Weight Lifting and } \\
\text { Transportation }\end{array}$} & Never & $23(10.8 \%)$ & $13(8.7 \%)$ \\
\hline & Rarely & $65(30.5 \%)$ & $24(16.0 \%)$ \\
\hline & Usually & $107(50.2 \%)$ & $84(56.0 \%)$ \\
\hline & Always & $18(8.5 \%)$ & $29(19.3 \%)$ \\
\hline \multirow{3}{*}{ Kneel Down Position } & Never & $51(23.9 \%)$ & $27(18.0 \%)$ \\
\hline & Rarely & $44(20.7 \%)$ & $44(29.3 \%)$ \\
\hline & Usually & $118(55.4 \%)$ & $79(52.7 \%)$ \\
\hline \multirow{2}{*}{ Lying Down Position } & Never & $163(76.5 \%)$ & $105(70.0 \%)$ \\
\hline & Rarely & $50(23.5 \%)$ & $45(30.0 \%)$ \\
\hline \multirow{4}{*}{ Sitting Position } & Never & $42(19.7 \%)$ & $32(21.3 \%)$ \\
\hline & Rarely & $110(51.6 \%)$ & $69(46.0 \%)$ \\
\hline & Usually & $50(23.5 \%)$ & $30(20.0 \%)$ \\
\hline & Always & $11(5.2 \%)$ & $19(12.7 \%)$ \\
\hline
\end{tabular}


Table 2 - Distribution of absolute and relative frequencies of ergonomic characteristics of the elderly participants

\begin{tabular}{lccc}
\hline & & \multicolumn{2}{c}{ Gender } \\
\cline { 2 - 4 } \multicolumn{1}{c}{ Factors } & Answer & Male $(\mathbf{n}=\mathbf{2 1 3})$ & Female $(\mathbf{n}=\mathbf{1 5 0})$ \\
\hline \multirow{3}{*}{ Sitting and Lifting Weight } & Never & $86(40.4 \%)$ & $54(36.0 \%)$ \\
& Rarely & $103(48.4 \%)$ & $68(45.3 \%)$ \\
& Usually & $24(11.3 \%)$ & $28(18.7 \%)$ \\
\hline \multirow{3}{*}{ Sitting and Leaning the } & Never & $42(19.7 \%)$ & $33(22.0 \%)$ \\
Body & Rarely & $94(44.1 \%)$ & $66(44.0 \%)$ \\
& Usually & $72(33.8 \%)$ & $38(25.3 \%)$ \\
Standing Position & Always & $5(2.3 \%)$ & $13(8.7 \%)$ \\
& Rarely & $11(5.2 \%)$ & $11(7.3 \%)$ \\
Standing and Leaning the & Usually & $32(15.0 \%)$ & $33(22.0 \%)$ \\
Body & Always & $170(79.8 \%)$ & $106(70.7 \%)$ \\
& Never & $5(2.3 \%)$ & $3(2.0 \%)$ \\
& Rarely & $13(6.1 \%)$ & $12(8.0 \%)$ \\
\hline
\end{tabular}

Table 3 - Bivariate analysis among sociodemographic characteristics, referred morbidity, physical activity and low back pain in elderly people

\begin{tabular}{|c|c|c|c|c|}
\hline \multirow[b]{2}{*}{ Factors } & & \multicolumn{2}{|c|}{ Low back pain } & \multirow[t]{2}{*}{$P$ value } \\
\hline & & Yes & No & \\
\hline \multirow{2}{*}{ Age } & 60 to 79 & $107(52,7 \%)$ & 89 (55.6\%) & \multirow{2}{*}{$p>0.05$} \\
\hline & 60 or more & $96(47,3 \%)$ & $71(44.4 \%)$ & \\
\hline \multirow{2}{*}{ Gender } & Female & $97(47.8 \%)$ & $53(33.1 \%)$ & \multirow{2}{*}{$p>0.05$} \\
\hline & Male & $106(52.2 \%)$ & 107 (66.9\%) & \\
\hline \multirow{2}{*}{ Skin Color } & White/Black & $92(45.3 \%)$ & 79 (49.4\%) & \multirow{2}{*}{$p>0.05$} \\
\hline & Brown/Mulatto & $111(54.7 \%)$ & 81 (50.6\%) & \\
\hline \multirow{2}{*}{ Marital Status } & Married & $122(60.1 \%)$ & $88(55.0 \%)$ & \multirow{2}{*}{$p>0.05$} \\
\hline & Widower, Single, Divorced & $81(39.9 \%)$ & $72(45.0 \%)$ & \\
\hline \multirow{2}{*}{ Level of Scholling } & 0 a 4 years & $103(50.7 \%)$ & 87 (54.4\%) & \multirow{2}{*}{$p>0.05$} \\
\hline & 5 a 8 years & $100(49.3 \%)$ & $73(45.6 \%)$ & \\
\hline \multirow{2}{*}{ Income } & Up to $1 \mathrm{NMW}$ & $54(26.6 \%)$ & $52(32.5 \%)$ & \multirow{2}{*}{$p>0.05$} \\
\hline & From 2 to 5 NMW & $149(73.4 \%)$ & $108(67.5 \%)$ & \\
\hline \multirow{2}{*}{ Referred Morbidity } & Up to 2 & 75 (36.9\%) & 28 (17.5\%) & \multirow{2}{*}{$p>0.05$} \\
\hline & 3 or more & $128(63.1 \%)$ & $132(82.5 \%)$ & \\
\hline \multirow{2}{*}{ Physical Activity Level } & Sedentary & 148 (72.9\%) & $132(82.5 \%)$ & \multirow{2}{*}{$p>0.05$} \\
\hline & Active & 55 (27.1\%) & 28 (17.5\%) & \\
\hline
\end{tabular}


Table 4 - Bivariate analysis among ergonomic variables and low back pain in elderly people

\begin{tabular}{|c|c|c|c|c|}
\hline \multirow[b]{2}{*}{ Factors } & \multirow[b]{2}{*}{ Answer } & \multicolumn{2}{|c|}{ Low back pain } & \multirow[t]{2}{*}{$P$ value } \\
\hline & & Yes & No & \\
\hline \multirow{2}{*}{ Repetitive movements } & Never/ Rarely & $29(14.3 \%)$ & $35(21.9 \%)$ & \multirow{2}{*}{$p<0.05$} \\
\hline & Usually/Always & $174(85.7 \%)$ & $125(78,1 \%)$ & \\
\hline \multirow{2}{*}{$\begin{array}{l}\text { Vibration and/or } \\
\text { trepidation }\end{array}$} & Never/Rarely & $115(56.7 \%)$ & 93 (58.1\%) & \multirow[b]{2}{*}{$p<0.05$} \\
\hline & Usually/Always & $88(43.3 \%)$ & $67(41,9 \%)$ & \\
\hline \multirow{2}{*}{$\begin{array}{l}\text { Weight Lifting and } \\
\text { Transportation }\end{array}$} & Never/Rarely & 77 (37.9\%) & $48(30.0 \%)$ & \multirow{2}{*}{$p<0.05$} \\
\hline & Usually/Always & $126(62.1 \%)$ & $112(70 \%)$ & \\
\hline \multirow{2}{*}{ Kneel Down Position } & Never/Rarely & $93(45.8 \%)$ & $73(45.6 \%)$ & \multirow{2}{*}{$p<0.05$} \\
\hline & Usually/Always & $110(54.2 \%)$ & $87(54,4 \%)$ & \\
\hline \multirow{2}{*}{ Sitting position } & Never/Rarely & $143(70.4 \%)$ & $110(68.8 \%)$ & \multirow{2}{*}{$p<0.05$} \\
\hline & Usually/Always & $60(29.6 \%)$ & $50(31,2 \%)$ & \\
\hline \multirow{2}{*}{ Sitting and Lifting Weight } & Never/Rarely & $178(87.7 \%)$ & $133(83.1 \%)$ & \multirow{2}{*}{$p<0.05$} \\
\hline & Usually/Always & $25(12.3 \%)$ & 27 (16,9\%) & \\
\hline \multirow{2}{*}{$\begin{array}{l}\text { Sitting and Leaning the } \\
\text { body }\end{array}$} & Never/Rarely & $134(66.0 \%)$ & $101(63.1 \%)$ & \multirow{2}{*}{$p<0.05$} \\
\hline & Usually/Always & $69(34.0 \%)$ & $59(36,9 \%)$ & \\
\hline \multirow{2}{*}{ Standing position } & Never/Rarely & $11(5.4 \%)$ & $11(6.9 \%)$ & \multirow{2}{*}{$p<0.05$} \\
\hline & Usually/Always & $192(94.6 \%)$ & $149(93,1 \%)$ & \\
\hline \multirow{2}{*}{$\begin{array}{l}\text { Standing and Leaning the } \\
\text { body }\end{array}$} & Never/Rarely & $15(7.4 \%)$ & $18(11.2 \%)$ & \multirow{2}{*}{$p<0.05$} \\
\hline & Usually/Always & $188(92.6 \%)$ & $142(88.8 \%)$ & \\
\hline
\end{tabular}

Table 5 - Poisson's regression analysis for low back pain in elderly people

\begin{tabular}{|c|c|c|c|}
\hline Factor & & Value of $p$ & Adjusted PR* / Cl 95\% \\
\hline \multirow{2}{*}{ Age (years) } & 60 to 69 & \multirow{2}{*}{0.40} & 1.00 \\
\hline & 70 or more & & $0.92(0.81-1.89)$ \\
\hline \multirow{2}{*}{ Gender } & Female & \multirow{2}{*}{0.44} & 1.00 \\
\hline & Male & & $1.08(0.80-2.01)$ \\
\hline \multirow{2}{*}{ Skin Color } & White & \multirow{2}{*}{0.86} & 1.00 \\
\hline & Black/Brown/Mulatto & & $1.01(0.90-1.38)$ \\
\hline \multirow{2}{*}{ Marital Status } & Married & \multirow{2}{*}{0.71} & 1.00 \\
\hline & Widowers, Singles, Separated & & $0.96(0.76-2.31)$ \\
\hline \multirow{2}{*}{ Level of Scholling } & 0 to 4 years & \multirow{2}{*}{0.16} & 1.00 \\
\hline & 5 to 8 years & & $1.17(0.81-1.95)$ \\
\hline \multirow{2}{*}{ Income } & Until $1 \mathrm{MNW}$ & \multirow{2}{*}{0.66} & 1.00 \\
\hline & From 2 to $5 \mathrm{MNW}$ & & $0.96(0.85-1.68)$ \\
\hline \multirow{2}{*}{ Referred Morbidity } & Until 2 diseases & \multirow{2}{*}{0.04} & 1.00 \\
\hline & Three or more diseases & & $1.75(1.29-4.41)$ \\
\hline \multirow{2}{*}{ Physical Activity } & Sedentary & \multirow{2}{*}{0.99} & 1.00 \\
\hline & Active & & $0.99(0.82-1.81)$ \\
\hline \multirow{2}{*}{ Repetitive Movements } & Never/Rarely & \multirow{2}{*}{0.68} & 1.00 \\
\hline & Generally/Always & & $0.90(0.75-2.50)$ \\
\hline \multirow{2}{*}{ Vibration/ Trepidation } & Never/Rarely & \multirow{2}{*}{0.72} & 1.00 \\
\hline & Generally/Always & & $1.03(0.79-2.04)$ \\
\hline \multirow{2}{*}{ Weight Lifting and Transportation } & Never/Rarely & \multirow{2}{*}{0.001} & 1.00 \\
\hline & Generally/Always & & $1.70(1.02-3.49)$ \\
\hline \multirow{2}{*}{ Kneel Down Position } & Never/Rarely & \multirow{2}{*}{0.78} & 1.00 \\
\hline & Generally/Always & & $1.04(0.77-2.23)$ \\
\hline \multirow{2}{*}{ Sitting Position } & Never/Rarely & \multirow{2}{*}{0.92} & 1.00 \\
\hline & Generally/Always & & $1.01(0.74-2.54)$ \\
\hline
\end{tabular}


Table 5 - Poisson's regression analysis for low back pain in elderly people

\begin{tabular}{|c|c|c|c|}
\hline Factor & & Value of $p$ & Adjusted $\mathrm{PR}^{*} / \mathrm{Cl} 95 \%$ \\
\hline Sitting and Lifting Weight & $\begin{array}{c}\text { Never/Rarely } \\
\text { Generally/Always }\end{array}$ & 0.84 & $\begin{array}{c}1.00 \\
1.01(0.74-2.51)\end{array}$ \\
\hline Sitting and Leaning the body & $\begin{array}{c}\text { Never/Rarely } \\
\text { Generally/Always }\end{array}$ & 0.82 & $\begin{array}{c}1.00 \\
0.98(0.78-2.14)\end{array}$ \\
\hline Standing Position & $\begin{array}{c}\text { Never/Rarely } \\
\text { Generally/Always }\end{array}$ & 0.27 & $\begin{array}{c}1.00 \\
1.57(0.65-3.74)\end{array}$ \\
\hline Standing and Leaning the body & $\begin{array}{c}\text { Never/Rarely } \\
\text { Generally/Always }\end{array}$ & 0.96 & $\begin{array}{c}1.00 \\
0.99(0.82-1.81)\end{array}$ \\
\hline
\end{tabular}

Note: *Adjusted by gender, age range, education and income.

In this study, the prevalence of low back pain was similar to the related in a city in the southwest of Bahia (6) and in the South region of Brazil (15), higher than the one verified in the USA (4), Goiânia (7) and in the city of São Paulo (8) and, lower than the one found in Maryland, USA (19) and in Santa Catarina (20).

The estimates of the prevalence of low back pain in older populations vary very much because of the differences in the definition and sampling strategies, making it difficult the comparison of results. A higher prevalence is found when research is conducted within a population of institutionalized elderly people or when they linked to the Public Health System, but this difference seems to be justified, because such elderly people report important morbidities. Specific studies about the subject "pain" usually find a higher prevalence than on surveys about health in which pain is only a variable of analysis. For the full comprehension of these variables, other studies are necessary $(19,21)$.

Considering the age range, the higher prevalence occurred in individuals with ages ranging from 60 to 69 years old (55.8\%), both from the female $(52.6 \%)$ as well as male gender (52.8\%), which is similar to other studies $(6,9)$. This result may be due to the fact that individuals aged 60 to 69 years old, in general, are more active and keep professional activities even after retiring, something that occurs less for the majority of people above this age range $(6,22)$.

Studies suggest that many factors could explain a decrease in the prevalence of low back pain along the ageing process, including cognitive impairment, depression, decreased perception of the pain and more tolerance to the pain. Furthermore, investigations frequently include people who live in institutions, such as nursing homes, and these individuals may have a higher prevalence of low back pain in comparison with those who live within a community (21).

In the present study, there was not a significant association of low back pain with gender, supporting some previous studies $(10,20)$. Meanwhile, the majority of studies support that women show a higher risk of suffering from low back pain than men $(3,7$, 22 ), because women increasingly combine household chores with jobs away from home in which they are exposed to ergonomic charges, mainly those that are related to repeatability, vicious position and work performed in high speed. Women also display some anatomical and functional characteristics (low height, lower muscle mass, less dense bone mass, more fragile joints that are less adapted to heavy physical effort and higher fat weight) which may collaborate to the emergence of chronic low back pain (20).

The fact that there was not an association may be due to the socioeconomic characteristics of the studied population, composed by individuals with a lower educational level and income, and who perform heavy occupational activities (such as the transport and lifting of weight, both standing and standing leaning the body). In a systematic revision, the authors relate that studies performed in countries of low and medium income, where individuals start performing occupational activities at an early age, there were not significant differences between genders on the prevalence of low back pain (21).

Transport and lift weight was the ergonomic exposure variable that remained associated with the outcome in the final model and are according with the literature findings $(10,23)$. Some models have been 
developed to explain back pain. In the first place, as charge increases, there is an increase in the oxygen consumption rate, in the compression of the discs, of the ligaments and capsules, generating a response which can imply in tissue inflammation, edema and biochemical responses. Biomechanical studies report that mechanisms of feedback can influence the biomechanical charge and its response. For example, pain can take an individual to use their muscles differently, changing his pattern of transportation and lifting weight. This adaptation allows the individual to expose himself to larger charges than he is able to support (24).

Low back pain presented a significant association with the high prevalence of individuals who claim to have three or more diseases, showing an agreement with other studies $(25,26)$. The presence of pathological disorders makes the individual more prone to feel pain. Thus, the ones with individual predisposing risks to pain conditions are the previous experiments and similar pathological symptoms in other parts of the body (27). Costa and Vieira (28) have reported that this interpretation is difficult because of the fact that most studies are cross-sectional and, therefore, the association of symptoms with the diseases can be interpreted as a cause or as an effect.

The level of physical activity did not present association with low back pain, in the final model of regression, corroborating with data from Silva (3), while other studies show a positive association between these variables $(29,30)$. The lack of association could reflect a bias of reverse causality, namely, people with back pain have become sedentary because of the pain (3).

Limitations should also be considered. The measures were based on self-reports and collected in a short period of time. In some cases, it may have occurred, mainly on the symptoms, the difficulty of older people in remembering about the presence or absence of pain after twelve months, however, the survey of the Musculoskeletal Pain Nordic Questionnaire agrees with a clinical evaluation. Considering the cross-sectional design of the study, one can't infer any causality, only association. Consequently, it can't be judged whether the features of an activity are mediated by experiences of pain in the lumbar spine regions, being that the elderly who have pain avoid activities that propagate pain, thus eliminating any association in a cross-sectional analysis. Therefore, it will be important for a prospective study to investigate the association between the pain and the variables. An extremely favorable point of this study was the use of validated questionnaires for the Brazilian population, as well as having collected data of the elderly people with the same socioeconomic level.

The data of this study on prevalence and factors associated with pain in the lumbar spine in elderly patients contribute to preventive strategies in public health, disclosing the risks of the occupational activities that require the transportation and lifting of weight, the associated morbidity and other risk factors for the development of low back pain, as well as encouraging the periodic monitoring of health. It is important to point out that the physiotherapist involved in activities for the elderly should be able to understand the relationships between variables, as well as be attentive to evaluate and interpret the correlations between clinical conditions and develop multifocal strategies on the human movement in all its forms of expression and pathological changes in potential, kinetic-functional, and in its psychological effects and organic, aiming to preserve, develop and restore the integrity of organs, systems and functions.

\section{Conclusion}

This work revealed a high prevalence of pain in the lumbar spine and a striking association with individuals who exercise their occupational activities involving, usually or always, the transportation and lifting of weight and in seniors who reported three or more of the diseases.

\section{Acknowledgement}

Special thanks to the elderly participants, the Family Health Program of Vila São Paulo and FAPESP (the Foundation for the Support of Teaching and Research of the State of São Paulo) for financing this project.

\section{References}

1. Instituto Brasileiro de Geografia e Estatística. Síntese de indicadores sociais: uma análise das condições de vida da população brasileira, 2010. Rio de Janeiro: Instituto Brasileiro de Geografia e Estatística; 2010. Portuguese. 
2. Rossi ALS, Pereira VS, Driusso P, Rebelatto JR, Ricci NA. Perfil do idoso na fisioterapia e sua relação com a incapacidade funcional. Braz J Phys Ther. 2013;17(1):77-85.

3. Silva MC, Fassa AC, Valle NCJ. Dor lombar crônica em uma população adulta do Sul do Brasil: prevalência e fatores associados. Cad Saude Publica. 2004;20(2):377-85.

4. Von Korff M, Crane P, Lane M, Miglioretti DL, Simon G, Saunders K. Chronic spinal pain and physicalmental comorbidity in the United States: results from the national comorbidity survey replication. Pain. 2005;113(3):331-9.

5. Ursine PGS, Cordeiro HÁ, Moraes CL. Prevalência de idosos restritos ao domicílio em região metropolitana de Belo Horizonte (Minas Gerais, Brasil). Cienc Saude Colet. 2011;16(6):2953-62.

6. Reis LA, Mascarenhas CHM, Marinho Filho LEN, Borges PS. Lombalgia na terceira idade: distribuição e prevalência na Clínica Escola de Fisioterapia da Universidade Estadual do Sudoeste da Bahia. Rev Bras Geriatr Gerontol. 2008;11(1):93-103.

7. Pereira LV, Vasconcelos PP, Souza LAF, Pereira GA, Nakatani AYK, Bachion MM. Prevalência, intensidade de dor crônica e autopercepção de saúde entre idosos: estudo de base populacional. Rev Latino-Am Enfermagem. 2014;22(4):662-9.

8. Dellaroza MSG, Pimenta CAM, Duarte YA, Lebrão ML. Dor crônica em idosos residentes em São Paulo, Brasil: prevalência, características e associação com capacidade funcional e mobilidade (Estudo SABE). Cad Saude Publica. 2013;29(2):325-34.

9. Janwantanakul P, Pensri1 P, Moolkay P, Jiamjarasrangsi W. Development of a risk score for low back pain inoffice workers-a cross-sectional study. BMC Musculoskelet Disord. 2011;12(23):2-8.

10. Lebrão ML, Laurenti R. Saúde, bem-estar e envelhecimento: o estudo SABE no Município de São Paulo. Rev Bras Epidemiol. 2005;8(2):127-41.

11. Silveira MM, Pasqualotti A, Colussi EL, Vidimar MF, Wibelinger LM. Physical therapeutic approach in low back pain in the elderly. Rev Bras Cien Saude. 2010;8(25):56-61.
12. Stefane T, Santos AM, Marinovic A, Hortense P. Dor lombar crônica: intensidade de dor, incapacidade e qualidade de vida. Acta Paul Enferm. 2013;26(1):14-20.

13. Craig CL, Marshall AL, Sjostrom M, Bauman AE, Booth ML, Ainsworth BE, et al. International physical activity questionnaire: 12-country reliability and validity. Med Sci Sports Exerc. 2003;35(8):1381-95.

14. Palma R, Conti MHS, Quintino NM, Gatti MAN, Simeão SFAP, Vitta A. Functional capacity and its associated factors in the elderly with low back pain. Acta Ortop Bras. [online]. 2014;22(6):295-9.

15. Trize DM, de Conti MHS, Gatti MAN, Quintino NM, Simeão SFPA, Vitta A. Factors associated with functional capacity of elderly registered in the Family Health Strategy. Fisioter Pesq. 2014;21(4):378-383.

16. Pinheiro FA, Tróccoli BT, Carvalho CV. Validação do Questionário Nórdico de Sintomas Osteomusculares: validade do instrumento como medida de morbidade. Rev Saude Publica. 2002;36(3):307-12.

17. Celich KLS, Galon C. Dor crônica em idosos e sua influência nas atividades da vida diária e convivência social. Rev. Bras. Geriatr. Gerontol. 2009;12(3):345-359.

18. Zocchetti C, Consonni D, Bertazzi PA. Relationship between prevalence rate ratio and odds-ratio in crosssectional studies. Int J Epidemiol. 1997;26:220-3.

19. Fejer R, Ruhe A. What is the prevalence of musculoskeletal problems in the elderly population in developed countries? A systematic critical literature review. Chiropr Man Therap. 2012;20(31):2-52.

20. Hicks GE, Gaines JM, Shardell M, Simonsick EM. Associations of Back and Leg Pain With Health Status and Functional Capacity of Older Adults: Findings From the Retirement Community Back Pain Study. Arthritis Rheum. 2008;59(9):1306-13.

21. Gioda FR, Mazo GZ, Silva AH, Virtuoso JF. Dor Lombar: Relação entre Sexo e Estrato Etário em Idosos Praticantes de Atividades Físicas. Fit Perf J. 2010;9(1):46-51.

22. Hoy D, Bain C, Williams G, March L, Brooks P, Blyth F, et al. A systematic review 285 of the global prevalence of low back pain. Arthritis Rheum. 2012;64(6): 2028-37. 
23. Santos A, Burtia J, Lopesb J, Scazufcac M, Marquesa A, Pereirab R. Prevalence of fibromyalgia and chronic widespread pain in communitydwelling elderly subjects living in São Paulo, Brazil. Maturitas. 2010;67(3):251-5.

24. Mazloum A, Nozad H, Kumashiro M. Occupational low back pain among workers in some small-sized factories in Ardabil, Iran. Ind Health. 2006;44(1):135-9.

25. Dellaroza M, Furuya R, Cabrera M, Matsuo T, Trelha C, Yamada K, et al. Caracterização da dor crônica e métodos analgésicos utilizados por idosos na comunidade. Rev Assoc Med Bras. 2008;54(1):36-41.

26. Tunks E, Crook J, Weir R. Epidemiology of chronic pain with psychological comorbidity: prevalence, risk, course, and prognosis. Can J Psychiatry. 2008;53(4):224-34.

27. Maciel ACC, Fernandes MB, Medeiros LS. Prevalência e fatores associados à sintomatologia dolorosa. Rev Bras Epidemiol. 2006;9(1):94-102.
28. da Costa BR, Vieira ER. Risk factors for workrelated musculoskeletal disorders: A systematic review of recent longitudinal studies. Am J Ind Med. 2010;53(3):285-323.

29. De Vitta A, Canonici AA, Conti MHS, Simeão SFAP. Prevalência e fatores associados à dor musculoesquelética em profissionais de atividades sedentárias. Fisioter Mov. 2012;25(2):273-80.

30. Henchoz Y, Kai-Lik So A. Exercise and nonspecific low back pain: a literature review. Joint Bone Spine. 2008;75(5):533-9.

Received in $05 / 22 / 2015$

Recebido em 22/05/2015

Approved in 08/11/2016

Aprovado em 11/08/2016 